\title{
CATO IN LIBYA (LUCAN 9)
}

\author{
Alessandro Rolim de Moura
}

Universidade Federal do Paraná

Resumo. Após a derrota e o assassinato de Pompeu, Catão tenta reorganizar as forças republicanas no Norte da África. Sua luta é política e filosófica. Lucano apresenta esse desafio através dos discursos de Catão e seus interlocutores, bem como através de uma fantástica travessia do deserto líbio. Este trabalho procura mostrar como a forma da narrativa expõe os dilemas das personagens e do próprio narrador diante da crise representada por esse momento. Estudaremos sobretudo a ordenação dos conteúdos, as intervenções do narrador, o emprego das falas em discurso direto e a manipulação da geografia africana.

Palavras-chave. Lucano, Catão, narratologia, África, geografia.

This PaPer Will Study the Figure of Cato in book 9 of Lucan's CiViL War and his verbal interactions with other characters and the narrator, seeking to clarify elements of continuity and change in relation to the previous books, most particularly book 2 , considering the new context provided by this late stage of the war. Roman North Africa, which is depicted as a mysterious and hostile land capable of putting any firm scientific explanations and moral stances to the test, will interfere with the coherence of the poem's discourse, introducing elements of doubt into the various forms of consciousness attempting to fight their way out of civil-war perplexities. Hence my preoccupation with determining some of the features of Lucan's description of the place that do not stand comfortably in a work purporting to build a nonmythological view of reality and my highlighting of some details of ancient African geography that receive unclear or distorted treatment in the poem.

The words used by the narrator to introduce and comment on the characters' speeches will receive special attention. The questionable justification of Cato's action in book 9 brings us back to the discussion of his reasoning in book 2 (in which he explains why he is taking part in the civil war) and to the elements of passion we can identify in his attitude. At the same time, when differentiating the narrator's stance from Cato's, we will observe that the former is characterised by outbursts of emotion, in con- 
tradistinction to the latter's impassive behaviour. This will perhaps sound contradictory as book 9 will also furnish indications that there is some passion, or even madness, underlying Cato's uirtus and Stoic temperance. The solution, in my opinion, is to conceptualise the general's worldview looking for inspiration in phenomena described by $20^{\text {th }}$-century theory of ideology. ${ }^{1}$ Ideological constructions often incorporate a willful distortion of reality, ingrained hatred and prejudice or other features that science would regard as irrational. This does not preclude, however, such irrationality appearing as reason to its supporters; nor is it impossible for said irrationality to come to terms with external emotional control. It is not improbable that Lucan might have intuited this and tried to give poetic form to that perception in the figure of Cato. The ideological nature of Cato's position is also evident from the way his ideas have a strong bearing on his actions and from his efforts to change the way his men see the world.

Traits of criticism of Cato in the poem should not make us believe that he is absolutely identical to Caesar in ethical and political terms. A comparison between the two characters will demonstrate that and do so in a way which is favourable to Cato. Yet Cato is ambiguous and the ambiguity of his role is further explained by the ambiguity of the narrator himself: the latter is simultaneously critical of and identifies with the character, and the problem is partly allegorised by the ambiguity of nature in Libya. This basic dilemma in Lucan's approach to Cato is more delicate, complex and enigmatic than the contrast between the poet's hatred of Caesar's policies and ideas and his admiration for the character's spectacular epic heroism and military talent ${ }^{2}$ because, in the case of Cato, the contradiction is almost impossible to break up into easily visible opposing elements: this contradiction is ideological in a deeper sense; it stands closer to the fundamental political and philosophical anxieties of Lucan's view and to the challenge of depicting "the other", particularly of depicting a person whom an artist sincerely admires and regards as having tried to realise what he himself would like to realise. For if there is to be a way out of injustice in the poem, this must come from Cato. But will he live up to such expectations? The abundance of fantastic passages in book 9 and numerous indications of intellectual failure on the part of the characters and the narrator bring out the fact that the narrating voice itself has been represented as struggling to understand the

${ }_{1}^{1}$ See Rolim de Moura 2008, ch. 1, esp. 16-17, 24-5, and ch. 2, esp. 128 (with n. 2); Rose (2006, 103): "ideology is not simply propaganda, which is preeminently conscious manipulation [...], because ideology's goal is not only the subjugation of an underclass but the fostering of the self-esteem of the [dominant] group. [...] it is a self-serving set of deeply held, often unconscious beliefs".

${ }^{2}$ For this contrast, see Masters 1992. 
paradox of Cato's political adventure in a surreal Africa. This is also an indication that the war has arrived at a new and more desperate stage.

\section{CRITICISM OF CATO IN A MYTHOLOGICAL LIBYA}

Cato's march across the desert is often regarded as a particularly challenging episode in the poem. ${ }^{3}$ The aim of the journey is not clear at all and its justification, ambiguous from the start. In the historical sources, ${ }^{4}$ the route is altogether different, the objective, defined; the necessary precautions for such a risky enterprise are not neglected and we learn of no detours. The path in Lucan, on the contrary, is described only vaguely and seems quite random and unreasonable. The stunning "battle" against the serpents drives the poet's habitual grotesque to the edge of surrealism, ${ }^{5}$ the impression of the fantastic being enhanced by a long digression about Medusa which prepares for the arrival of the snakes, in fact situating the reptiles' origin in a non-scientific, frankly mythological aetiology. The encounter with the Psylli, whose powers of enchantment frame the army's salvation with a suitably magical coda, is the last time we hear of Cato in Lucan. Whether he ever planned to tell us much more about the hero is impossible to determine but it is clear that the author expected this tour de force to be a kind of grandiose aristeia, wherein humour, if any, is of the bitter variety.

The interpretations which this episode has called forth could hardly be more varied. ${ }^{6}$ Among the plethora of critical positions, the once-popular idea of unconditional praise of Cato has been submitted to criticism in recent Anglophone scholarship. Particularly representative are the influential works of W. R. Johnson and Matthew Leigh.' Quomodo Poeta Catonem Rid-

\footnotetext{
3 See e.g. Viarre 1982, 103, and Hutchinson 1993, 169.

${ }^{4}$ On which see below n. 54.

${ }^{5}$ For more on the grotesque in general and its manifestation in Lucan, Seneca, and $20^{\text {th }}$-century literature, see Sell 1987.

${ }^{6}$ Recalling some of them in synthetic form might give an idea of this. Cato's march has been interpreted as expressing the Stoic paradox of selfish selflessness (Shoaf 1978), the failure of Stoicism to control passion (Leigh 1997, 265-82, developed in Leigh 2000), Cato's maniacal obsession with death (Saylor 2002), metaliterary games with the epic tradition (Eldred 2000), the tragedy of Rome's good general (Narducci 2001), Cato as super-Hercules (Ahl 1976, 260) or anti-Alexander (cf. Ahl 1976, 258-9, 263, 267, 273-4), Cato as the expression of the ideal of primitive barbarism (Thomas 1982, 108-23), etc.

${ }^{7}$ Johnson 1987, 35-66, and Leigh 1997, 265-82. See also Seo 2011 and Tipping 2011. For a different view of Lucan's Cato, representing the interpretation that is dominant in Italy, see e.g. Narducci 2001. Outside Italy, note e.g. Schmitt 1995, 190-1, Kany-Turpin 2005, 144, and D'Alessandro Behr 2007. In my view, Bexley 2010 offers a more balanced assessment of the character.
} 
iculum Fecerit would be a fitting title for a typical doctoral thesis nowadays. Cato abandons all hope of being taken seriously and, as general criticism of the character and aversion to Stoicism unconsciously slide into debasement of the poem, his last aspiration is to be regarded as striving to show his virtue, Lucan's inept panegyric notwithstanding. Can we at least partially rescue the hero's dignity?

Undoubtedly, there are many references to earth and tombs in book 9, something of a chthonic wild energy that threatens to eclipse Cato's rationality. But the voyage is a challenge not only because of the inhospitable conditions of nature in Libya. The new republican leader must also stand for his ideas against opposing orators: the representative of the rebel troops at 227-51, devastatingly contradicted at 256-83; Labienus at 550-63, who hears Cato's reply at 566-84; and, finally, the lamenting soldiers at $848-80$, to whom the general offers no verbal answer. To these we must add another discourse, though; it is apparently not a speech but constitutes an ideological problem as well, especially for the alternative religion of Cato: myth, in its traditional form, by no means allegorised by a philosophical interpretation, occupies in this book a position it is assigned in no other section of the work. It comes in two digressions, the first prompted by the Lake of Triton, in 348-67; the second at 619-733, a bulky passage on Medusa and her offspring. It is not merely the considerable number of lines reserved for them that makes such pieces stand out so explicitly: the alien quality of these discourses, their intrusive appearance in such a historical poem, is recognised and commented upon by the narrator himself (at 359-6o and 619-23). Something not that dissimilar to this occurs at 4.592, where, again in Libya, the story of Hercules and Antaeus (593-655) is presented through the mouthpiece of a rudis incola, an "uneducated native". The story comes to explain the name of a site, Antaei regna (590); nonetheless, the unreliability of the myth as a provider of advice for military action is made clear by how the narrator conveys the reaction of Curio, who feels encouraged by the narrative and by the fact that Scipio set up camp at the "lucky" place, thinking it will be good for him to stop there too (661-5).

In book 9, a different treatment unfolds. Whilst recalling a sequence of legends about the region in which Cato finds himself, the narrator complains (359-6o): inuidus, annoso qui famam derogat aeuo, / qui uates ad uera uocat. The primary question here is: who on earth is this envious figure demanding the "truth" from the poets? Isn't it this very poet's decision to write a non-mythological epos? The narrator here seems to be rebelling against rationalising or Euhemeristic accounts of Libyan myth. ${ }^{8}$ The mys-

${ }^{8}$ See esp. Agroetas ap. schol. A.R. 4.1396-99a (p. 315 Wendel; also at FHG vol. 4 p. 295 fr. $3=$ FGrHist 762, 3, a), D.S. 4.26.2-3 (=FGrHist 762, 3, b), and D.S. 4.27.1. 
terious country may have had an influence on the narrating consciousness, for here we are closer to the sky (and thus to the Olympian gods) than in any other land (351; cf. 432-3). ${ }^{9}$ Note that, when Cato is at the temple of Ammon, the poet says: "That there are gods in the place is proven by the lone green forest in the whole of Libya" (Braund's trans. of 522-3, esse locis superos testatur silua per omnem / sola uirens Libyen), another observation which sounds unusual in the mouth of the narrator but which gains force as it is put against Cato's refusal to consult the oracle, esp. in lines 576-7, where the hero asks: "Did he [sc. god] choose barren sands to prophesy to a few and in this dust submerge the truth?"10 The Lethon/Lethes, inducing forgetfulness, is nearby (355-6), and we should add that Herodotus (4.177-8) situated the Lotophagi on the African coast, not far from Lake Tritonis. ${ }^{11}$ Later, when the subject is the reason why there are so many dangerous snakes in Libya, scholarly knowledge must confess its insufficiency (619-23):

cur Libycus tantis exundet pestibus aer

fertilis in mortes, aut quid secreta nocenti

miscuerit natura solo, non cura laborque

noster scire ualet, nisi quod uolgata per orbem

fabula pro uera decepit saecula causa.

Why the Libyan air abounds in such great plagues,

prolific in death, or what hidden Nature

has mingled with her harmful soil, no care or toil of ours

can know; except that a legend, spread throughout the world,

has deceived the centuries in place of the real reason. ${ }^{12}$

This is followed by the Medusa excursus, where the blood falling from the monster's head freshly cut by Perseus is the origin of the pestes harenae. ${ }^{13}$ There were, though, scientific explanations in antiquity: e.g. Theophrastus,

\footnotetext{
${ }^{9}$ More on this below.

${ }_{10}$ Trans. adapted from Duff and Braund. For testor in 522 as "give evidence", and even "prove" or "demonstrate", see OLD 1933 s.v. testor 4.a, and Lewis \& Short 1864 s.v. testor I.B. Cf. Lucan 10.16, Hor. carm. 2.1.31, Sen. epist. 87.4. At 9.350-2, Lucan comments on the fact that Libya is nearest the sky to explain why Pallas, "[w] hen she was born from her father's head, [...] alighted on Libya before any other land" (trans. Duff).

${ }^{11}$ But see infra pp. 79-80 for the uncertainty about which lake Lucan has in mind.

${ }^{12}$ Trans. Braund.

${ }^{13}$ For a similar opinion on the origin of snakes and other poisonous animals, see Nicander's Theriaca 8-12, which states they came from the blood of the Titans and attributes this idea to

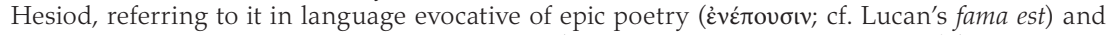

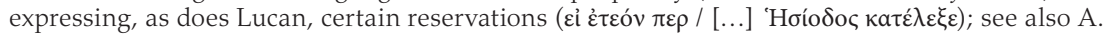
Supp. 264-7. Lucan's version is found in A.R. 4.1513-17. According to schol. Nic. Ther. 11, the same

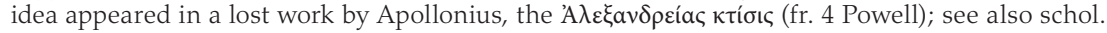
A.R. 4.1515a (p. 321 Wendel, plus the interpretation at Fränkel 1968, 606) and Ov. met. 4.617-20.
} 


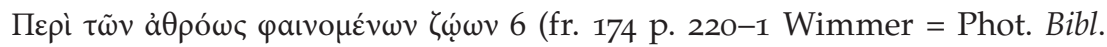
278.528a.19-23), thinks serpents may arise from two possible causes: "a

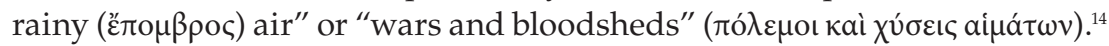
A relevant bloodshed in Libya in this herpetological context would be that of the Psylli, who are situated by Herodotus (4.173) in the region near the Syrtes. According to the historian, these people were swept away in a war against Notus, who buried them under the sand (Pliny nat. 7.14 tells a similar story, presenting the Nasamonians as the enemy in a war that killed almost all the Psylli). The point is that Lucan could easily have found a nonmythological explanation, his choosing of Perseus and Medusa being therefore probably deliberate. ${ }^{15}$ It is interesting to notice that Lucan describes how Medusa's blood is cooked together with poison and sand by the hot Libyan weather before giving rise to the serpents (9.697-9), pointing to a biological model of spontaneous generation analogous to the one employed by Lucretius in De rerum natura $2.897-901 .^{16}$ In other words, Lucan inserts myth into his text with surgical precision, in a very self-conscious way, and even suggests he could dispense with it.

The narrator confronts Cato with the snakes as an act of mockery. ${ }^{17}$ Of course, the exaggeration in Lucan's treatment is maybe not as great as one might think. If we consider the incredible things Pliny says about the

\footnotetext{
14 Theophrastus links his explanation with accounts of great numbers of serpents in Thessaly but it is not clear whether he means blood, humidity or both as the origin of the phenomenon in the region. See Plutarch De Iside et Osiride 74 (= Moralia 380f). Related passages are to be found in Rose, Aristoteles Pseudepigraphus p. 334 frr. 1 (= [Arist.] Mir. 832a14-21) and 3 (= Plin. nat. 10.62), Nic. Ther. 145, Sol. 40.27, Clem. Al. Protr. 2.39.6. The interest in snakes/herpetology in early imperial times was considerable: Nicander's Theriaca is translated/imitated by Aemilius Macer, a contemporary of Ovid, and Andromachus, a physician working under Nero, writes a Theriaca as well. Lucan roughly follows Nicander's scheme, talking first and foremost of snakes and then of other poisonous animals.

${ }^{15}$ For the influence of the habitat in the degree of venomousness of snakes, see Sall. Iug. 89.5, Cels. 5.27.10, Ov. met. 2.173-5, Sil. 1.285-6, Paus. 9.28.1-4 (Leigh 2000, 97-8 with n. 34). Lucan had sufficient material to explain the origin of so many pestes in the hot and dry climate of Libya. He actually comes close to that kind of explanation at 9.729 and 844-6.

${ }_{16}$ This is shown by Kany-Turpin 2005, 138-9, who also points out that the whole episode is inspired by ancient views on how an epidemic works.

17 See Ennod. opusc. 1 (p. 269, 20-4 Hartel): "quid Catonem extulistis, prisca monimenta, quod per Libycas Syrtes duxit exercitum, dum humanas neces ludibria faceret esse serpentum, uel cum sine uirtutis pretio educatum caeli uaporibus ueneni frigus expertus est?" Ennodius compares Cato to Theodoric in a way that is always unfavourable to the republican general, pointing out that Cato's soldiers who were killed by snakebite cannot be deemed to have died courageously as they did not know where death was coming from (p. 269, 24-270, 2 Hartel). Note also Ennodius' argument immediately afterwards: "nec illius militis cuneis tuis fortitudo comparanda est nec par est in duce sapientia. illum ciuilis belli furor agitabat: te orbis domina ad status sui reparationem Roma poscebat". The late antique writer obviously exaggerates Cato's shortcomings in order to extol the recipient of his panegyric, but his unsympathetic approach to Cato has many striking similarities with some recent interpretations of Lucan's character discussed in this paper.
} 
basiliscus at nat. 8.78 or the aspides at 8.86 , or Aristotle's remarks on Libyan animals at HA 6o6b.17-6o7a.1, we might conclude that (pseudo-)scientific discourse in antiquity could shelter many an absurdity. As Pliny himself argues (nat. 7.6-7),

[i]ndeed what is there that does not appear marvellous, when it comes to our knowledge for the first time? How many things, too, are looked upon as quite impossible, until they have been actually effected? But it is the fact, that every moment of our existence we are distrusting the power and the majesty of Nature, if the mind, instead of grasping her in her entirety, considers her only in detail.18

However, we should not forget that even brute reality can be a mockery: casual events or serious gestures may acquire an ironic bias depending on the viewpoint (see uidit quanta sub nocte iaceret / nostra dies risitque sui ludibria trunci at Lucan 9.13-14). Besides, Libya was still a fairly exotic place in

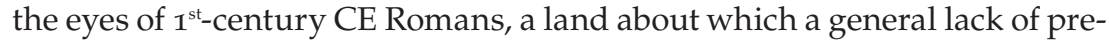
cise information opens up a great deal of freedom for poetic imagination. ${ }^{19}$ Therefore, satirical distortion in the reptiles episode is always a possibility. ${ }^{20}$

\section{CATO'S STRENGTH}

Yet, no matter how the narrator mocks Cato, he is, in a way, beyond derision. The confusion of his political thought, the proud insensibility he shows in his relationship with people, the remote, inaccessible kernel of his heart (his sacrum pectus) cannot be affected by exposure to all the ridiculous tragedy of war and human pain, regardless of the degree of intensification the narrator may apply to the description of violence and suffering. Cato's emotional impenetrability is his victory. Here we still have, in a way, what Morford described as the superiority of Stoic virtue to pain and death. ${ }^{21}$ Seneca dial. 1.3.14 can perhaps illuminate this problem:

${ }_{18}$ "quid non miraculo est, cum primum in notitiam uenit? quam multa fieri non posse prius quam sunt facta iudicantur? naturae uero rerum uis atque maiestas in omnibus momentis fide caret, si quis modo partes eius ac non totam complectatur animo" (trans. Bostock and Riley). One can argue that Pliny is thinking of paradoxographic sources as Archelaus' work on strange creatures (cited by D.L. 2.17). Pliny himself cites Archelaus several times (e.g. at nat. 1.18. ind. auctor., 8.202, 218). See Varro's repudiation of paradoxography at rust. 1.2.28; contrast 2.3.5, 2.4.12, 2.5.14, 2.7.9.

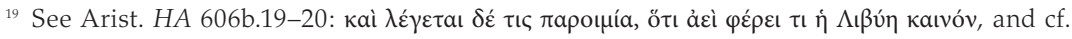
Plin. Nat. 8.42.

${ }^{20}$ Cazzaniga 1957 compares Lucan's treatment of the snakes to Nicander's and concludes that the former omits several technical details found in the latter, giving emphasis instead to horrific and shocking imagery and exaggerating the effects of snakebites. Similarly, Hutchinson 1993, 169.

${ }^{21}$ Morford 1967, 129. 
quod ad Catonem pertinet, satis dictum est, summamque illi felicitatem contigisse consensus hominum fatebitur, quem sibi rerum natura delegit cum quo metuenda conlideret. "inimicitiae potentium graues sunt: opponatur simul Pompeio, Caesari, Crasso. graue est a deterioribus honore anteiri: Vatinio postferatur. graue est ciuilibus bellis interesse: toto terrarum orbe pro causa bona tam infeliciter quam pertinaciter militet. graue est manus sibi adferre: faciat. quid per haec consequar? ut omnes sciant non esse haec mala quibus ego dignum Catonem putaui."

As far as Cato is concerned, enough has been said, and the consensus of men will grant that the fullest measure of happiness fell to that man, whom Nature chose to be the one to confront her dreaded power. "The enmity of powerful men makes for hardship", she said: "let him match himself against all three of Pompey, Caesar, and Crassus. It is a hardship to be overtaken by inferior men in competing for office: let him come behind Vatinius. It is a hardship to take part in civil wars: let him fight all the world over for a cause that is just, unsuccessful to the last and stubborn to the last. It is a hardship to do violence to oneself: let him do it. What shall I gain by this? That all may know that these trials I have considered worthy of Cato are not true ills." ${ }^{\prime 22}$

This passage fits well with a certain view of the wise man as equal or even superior to the gods, a conception which was popular with the Stoics and Cynics and which clearly influenced Lucan's portrait of Cato. ${ }^{23}$ And the character seems to be aware of that idea and quite self-contented.

There are possibly indications of a certain level of recognition of defeat in Cato's silence after the collective speech of his soldiers (9.848-80) and in the fact that the army turns to the Psylli (significantly put by Lucan at the end of the journey, almost as a deus ex machina, ${ }^{24}$ instead of being presented as part of the precautions taken by Cato before beginning the expedition, as in Plutarch). If so, the effect is only subtly hinted at and we can by no means be certain that the focalisation that sees this as a defeat is shared by Cato: we are witnessing a situation where the suggestion of Cato's failure comes predominantly from the narrator, from the way he structures the narrative; the character himself would not acknowledge his downfall. If, even after all those laments, the soldiers are ashamed to groan in front of their leader (9.886-7), this could be seen by him as sufficient proof that his pupils have learned something, although the speech itself sounds more like confirmation of the soldiers' failure to assimilate Cato's principles. ${ }^{25}$

In all his interventions, Cato is deeply self-assured, imperturbably stable within his uncommon ideas, not caring a jot if they are contradictory or difficult to share; he has acquired inner freedom, maybe at the cost of

${ }^{22}$ Trans. Davie.

${ }_{23}$ Oltramare 1926, 282, and La Penna 1980, 20-6 (the latter discussed in Rolim de Moura 2008, 119-20). The idea was not alien to Epicureanism: Lucr. 5.8, 19.

${ }^{24}$ See at 890-1 the idea that the Psylli are an aid offered by chance or Fortune.

${ }_{25}$ See p. 30-2 below for further discussion of this passage. 
alienating everyone else, and has lost any sense of proportion with regard to the external consequences of his actions. When the hero is on the point of starting his journey through the desert, the narrator himself, after rendering one of Cato's most revealing speeches, observes that, while Cato's future will be a small grave, he remains secure (406-10):

\section{[...] sic ille pauentis \\ incendit uirtute animos et amore laborum, ${ }^{26}$ \\ inreducemque uiam deserto limite carpit; \\ et sacrum paruo nomen clausura sepulchro \\ inuasit Libye securi fata Catonis.}

\section{[...] So he fires}

their frightened minds with heroism and with love of toils and takes the journey not to be retraced on desert track; and Libya, soon to shut his sacred name in a little tomb, laid its hands upon the destiny of Cato, who was above worry. ${ }^{27}$

First of all, although his soldiers may be aflame with heroism and a love of hard toil, they are still afraid. Of this Cato is aware and it is not his method to pretend there is no fear (see 388-9 and 612). He aims to have his men overcome their fear, though, and expects that it will be subjugated to virtue. The start of the march is described with a strong verb (carpit), which points to the action of pushing one's way or pressing on along a road; ${ }^{28}$ carpo naturally implies an act of selection, seizing or taking hold of things, ${ }^{29}$ and a certain nuance of control is suggested by the passage. It seems Lucan chooses this construction so as to build up a paradox with inuasit Libye, where a verb usually implying movement is unexpectedly employed with the place into which the character is entering as its subject, in a sort of hypallage. Naturally, inuado can mean "take hold", "lay hands on", its object in the line under analysis being fata. As we note that Libya attacks, or takes hold of, the destiny of "secure Cato" (fata obviously hinting at fixity, previous determination, notwithstanding the fact of invasion), we can see that line 410 itself carries another contradiction. The passage as a whole puns on roots meaning separation, protection (sacrum, clausura, sepulchro, securi), but suggests these states will be limited in a way. The hero's sacred name will

${ }^{26}$ See Verg. A. 6.889: "incenditque animum famae uenientis amore". This intertext hints at the hellish aspect of Cato's march (although the Vergilian line comes as Anchises escorts Aeneas out of the world below). The following line in Lucan (9.408) reinforces the idea of a journey to the world of the dead with "inreducemque uiam". See Viarre 1982, 106.

27 Trans. Braund.

${ }^{28}$ Lewis \& Short, 295 s.v. carpo II.B.3; OLD, 279 s.v. carpo 8.a; TLL III, 493.74-494.21 s.v. carpo I.D.

${ }^{29}$ Lewis \& Short, 294, 295 s.v. carpo II.A, B.2; OLD, 279 s.v. carpo 2.a, 4; TLL III, 494.24-6 s.v. carpo II.A. 
be enclosed by a small (notice the deceptive position of paruo) sepulchre. Here we have a renewal of the play on sacer we can find in book 2. ${ }^{30}$ On another plane, this is intended as a contrast with Cato's moral greatness: such a magnanimous man buried in a tiny grave! Yet he does not care, he is not the type of person who worries about luxury funerals, he is interested rather in "excellence [...] naked / with success removed" (Braund's translation of 9.594-5). However, we can hardly omit the presence of another, more critical focalisation mingling with the intricate words of the narrator at 406-10. It is a way of responding to Cato's harangue with sad and antithetic derision.

Still, the speech of encouragement before the start of the march (379-406) is concise, direct and to the point. At 379-80, the idea of an easy escape is immediately put aside, for their only hope of safety is to die free: "una salus [...] / indomita ceruice mori". Their mission is described at 381 as magnum uirtutis opus. At 385 , Cato makes clear that "[h]ard is the path towards legality and love of crashing fatherland" ("durum iter ad leges patriaeque ruentis amorem" in Braund's trans.). All this seems to be situated in an abstract sphere, concerned with emotional and moral aspects rather than military practicalities. The presence of leges may suggest they want to restore the republic but patriaeque ruentis conveys a sense of hopelessness; amorem, meanwhile, indicates that their quest is for emotional/spiritual development, forcing us to reinterpret leges in a way that is detached from the actual preservation of Rome. We must read it as the men's transformation into law-abiding citizens, as a matter of personal "moral salvation". That Cato's views are broader than mere legalism is demonstrated by his confrontation with the mutineers. Their representative rounds off his speech with a cynical observation about obedience to the law (9.249-51): "si publica iura, / si semper sequeris patriam, Cato, signa petamus / Romanus quae consul habet". It is Caesar who now holds the consulship. The narrator explicitly responds to this point brought up by the speaker and shows utter contempt for the mutiny (253-4): "actum Romanis fuerat de rebus, et omnis / indiga seruitii feruebat litore plebes". Cato's answer (256-83) attempts to show that the patria now lies elsewhere: Caesar's position is that of a tyrant. He mocks the soldiers' boastful pretence of respect for the law (266-7): "plus regia Nili / contulit in leges et Parthi militis arcus". In his view, the troops are victims of serious deception. That is why he sets himself up as a model for his men at 394-401. Why would we be surprised with the strangeness of their route since, according to Cato, "ire sat est" (388)? In 390-2 ("hi mihi sint comites, quos ipsa pericula ducent, / qui me teste pati uel quae tristissima

${ }^{30}$ For discussion, see Rolim de Moura 2008, 124. 
pulchrum / Romanumque putant") and 402-4 ("serpens, sitis, ardor harenae / dulcia uirtuti; gaudet patientia duris; / laetius est, quotiens magno sibi constat, honestum" ${ }^{31}{ }^{31}$ Cato's words show consistency with the way La Penna interprets his ideology, ${ }^{32}$ that is, all these hardships appear to Cato as a kind of askesis, of philosophical exercise to improve (and show off) one's endurance (patientia): the moral nature of the trip stands out again. The closure, though - envisaging the labours of Libya as a sort of compensation for the (supposedly shameful) flight at Pharsalus (405-6) - , sounds like unreasonable pride. Later on, when the soldiers speak, they seem to be conscious that their journey was supposed to bring knowledge, a discovery of something that had been set apart: "per secreta tui bellum ciuile recessus / uadit, et arcani miles tibi conscius orbis / claustra ferit mundi" (863-5). These lines and their context, bringing up once again the pervasive motif of separation (from society, from the known world) and encapsulation (in a strange land, under a strange fate), entertain a clear dialogue with the narrator's words at 406-10 (see above) and with Cato's educational project in general.

The contrast between, on the one hand, the hysterical desperation that at times affects the narrator, his sense of guilt, the madness, the grotesque, almost nightmarishly psychedelic imagery that his language can conceive and stretch out in gruesome detail, and, on the other hand, the constant determination of Cato, his oft-times irritating confidence, the way he quite naturally defends and imposes on others the by-products of his arguably unbalanced truth, — this dichotomy — is actually one of the greatest achievements of Lucan in terms of discursive representation.

\section{CATO, CAESAR, AND IDEOLOGY}

Hershkowitz argues that the way Cato clings to his ideas is so passionate that his uirtus is turned into a furor. ${ }^{33}$ Her citation of Sen. dial. 2.3.1 is indeed felicitous as an example of how a Roman philosopher could conceptualise a wise man going mad. ${ }^{34}$ For instance, Cato at $2.323-5$ is convincingly

\footnotetext{
${ }^{31}$ Lines 390-2 are thus translated by Duff: "I seek as my companions men who are attracted by the risks themselves, men who think it glorious and worthy of a Roman to endure even the worst, with me to watch them". Note Rowe's version of 9.402-4 (lines 683-6 of his text): "The sands, the serpents, thirst and burning heat / Are dear to patience and to virtue sweet — / Virtue, that scorns on cowards' terms to please, / Or cheaply to be bought, or won with ease."

32 La Penna 1980, 20-6.

${ }^{33}$ Hershkowitz 1998, 231-46.

${ }_{34}$ The passage is part of the objections raised by an imaginary interlocutor. Note especially the following: "cum sapientem negatis insanire, non negatis et alienari et parum sana uerba emittere et quidquid uis morbi cogit audere."
} 
shown by her to parallel Petreius at $4.235-6,{ }^{35}$ and his emphasis on the first person appears as "arrogance". ${ }^{36}$ We then reach another paradox, involving a passionate impassibility. Cato's plight suggests a type of megalomania not unrelated to Caesar's idea that Fortune is his ally, as if the universe had been structured around his desire of conquest. The parallel between Cato's "battle with the snakes" (I would say, more generally, his crossing of the desert) and Caesar's boat trip in book $5,{ }^{37}$ seen as arrogant tests of their power over nature and destiny, recalls the impious tests of the gods' intelligence attempted by Tantalus and other mythic characters. Caesar's individualism, though, is more concretely marked by the fact that he tries to cross the sea alone in a small boat, accompanied only by Amyclas, while Cato is keen to persuade his men to go with him and effectively lures them into the harshest dangers of Libya. Cato is thus bound to appear as an inverted Palinurus (see Lucan's direct reference to this Vergilian character at 9.39-44, where he is cited in connection with Libya, and immediately after the destruction of Phycus by Cato's forces) when the apparent sacrifice of one for all converts into a dreadfully massive death toll for one man's interests or moralistic obsessions. Hershkowitz may be correct to say that Caesar, in contrast, appears sometimes as the protector of his men, most conspicuously at 7.566-7, where he acts as a good general should, looking after the wounded, ${ }^{38}$ while Cato's teaching seems to be unable to conquer his troops' suffering. It would be inexact, though, to present Cato as definitely more dangerous than Caesar as a cause of disaster to people around him. The simple fact that Caesar, in an equivalent manner, or one that is even more selfish, leads thousands of people to war (and roughly the same could be said of Pompey) is reason enough to see him, euphemistically speaking, as a very heavy liability to mankind.

There is a basic difference between the two heroes: Caesar consciously exploits others to achieve his aims; his promises to the crowd

\footnotetext{
${ }^{35}$ Not all Heshkowitz's examples are as persuasive as this one though. While comparing 1.144-5 (re Caesar): "nescia uirtus / stare loco", with 9.371 (re Cato): "inpatiens uirtus haerere", Hershkowitz $(1998,238)$ perhaps exaggerates the implications of inpatiens ("that does not endure or tolerate, impatient (of)", probably well rendered by Ahl's suggestive "unwilling") as a sign of uncontrolled passion. Ahl $(1976,259)$ observes the importance of nescia as a distinguishing mark of Caesar's irrationality as opposed to Cato's philosophical option.

${ }^{36}$ Hershkowitz 1998, 239.

${ }^{37}$ Noticed by Ahl 1976, 259, and Hershkowitz 1998, 242.

${ }^{38}$ But 10.488-91 is dubious as an argument to prove such a characterisation of Caesar since, here, he is defending the army and himself in a battle scene, not necessarily showing any empathy with his men. With this, we might want to compare the fact that Cato becomes maestus (9.747) when he sees his men's suffering. He is still unable to admit he may have a responsibility for this pain but appears not to be completely indifferent (unless we take this sadness as his constant state of mind).
} 
that it will rule through him are noticeably mere bravado. They are not grounded in any sociological theory of the irrational power of the masses being channelled through their Führer: "humanum paucis uiuit genus", he says at 5.343. He protects his men and does everything to lighten their pain because this is the most effective way of dealing with the soldiers so as to obtain the maximum degree of commitment and loyalty. Cato, on the other hand, is indeed expecting to help his men, to make them ascend to his level of moral wisdom and psychic resistance and, if he says they should die for the republic, it is never because he morbidly revels in their destruction or consciously wants to use them to save an oppressive aristocratic regime where they usually had little voice, but because he thinks it is the only option for an honourable man. If we may attack him in terms of Marxist ideology critique, we cannot forget that ideology in Marxist thought can be seen as a false worldview capable of making injustice appear to one's mind as natural or even good. The journey has a kind of didactic purpose (see 889, docet). Cato wants to teach his men. His methods are completely sui generis, and, so to speak, do not have the commercial potential of Caesar's propaganda; the advantages Cato tries to seduce his men with are much more difficult to sell. Maybe his mistake is to think his pupils can perform his original mix of Stoicism and republicanism as quickly and perfectly as he can. His words when counterattacking the mutineers are clear. Let us read the initial lines (256-65):

ergo pari uoto gessisti bella, iuuentus,

tu quoque pro dominis, et Pompeiana fuisti

non Romana manus? quod non in regna laboras,

quod tibi, non ducibus, uiuis morerisque, quod orbem

adquiris nulli, quod iam tibi uincere tutum est,

bella fugis quaerisque iugum ceruice uacanti

et nescis sine rege pati. nunc causa pericli

digna uiris. potuit uestro Pompeius abuti

sanguine: nunc patriae iugulos ensesque negatis,

cum prope libertas?

It seems then, soldiers, that you too fought with the same desire as others, in defence of tyranny - that you were the troops of Pompey, and not of Rome. You no longer suffer in order to set up a tyrant; your life and death belong to yourselves, not to your leaders; there is no one for whom you gain the whole world, and now you may safely conquer for yourselves alone. Yet now you desert the ranks; you miss the yoke when your neck is relieved, and you cannot endure existence without a king. Now the cause of danger is worthy of brave men. Pompey was suffered to make full use of your life-blood: now, when freedom is near, do you refuse to fight and die for your country? ${ }^{39}$

${ }^{39}$ Trans. Duff (with minor adaptations). 
One may compare the immoderate self-glorification of Cato in book 2 with a passage like this, where the focus is on the second person. Also, we might remember that Cato apparently does not force the troops to go with him as he will clearly dismiss whoever does not wish to fight, ${ }^{40}$ whilst Caesar, when faced with a similar questioning of his authority (5.237-73), is eager to terrorise the soldiers who organised the mutiny. However, if we contextualise Cato's discourse in 9.217-93, a different picture will appear. There is discord and a Cilician leads the defection (217-20); Cato rebukes him (220-4). The others, Romans included, do not seem resigned (224-52); Cato criticises them all and restores order (256-93). The troops are then forced into discipline by marching and other exercise (294-5). The broader dialogical context tends to confirm the validity of Cato's views on the exploitation of soldiers by Caesar and Pompey. A particularly momentous response is that of the narrator at 596-600:

\author{
[...] quis Marte secundo, \\ quis tantum meruit populorum sanguine nomen? \\ hunc ego per Syrtes Libyaeque extrema triumphum \\ ducere maluerim, quam ter Capitolia curru \\ scandere Pompei... \\ [...] Who has earned a name so mighty \\ by favourable battle, who by blood of nations? \\ This triumphal march through the Syrtes and remotest parts of Libya \\ I would rather make than climb the Capitol three times \\ with Pompey's chariot... ${ }^{41}$
}

Here, both the glory of war and the price one pays for it (populorum sanguine) are vilified and we are approvingly sent back to 263-4, "potuit uestro Pompeius abuti / sanguine", and 2.474-7, esp. 474, "donauit socero Romani sanguinis usum", where the narrator had already formulated the idea, although discreetly. The reply at 9.596-60o thrusts the poet's ego onto the reader. Immediately after this, Lucan's narrator presents Cato as a man bound to be worshipped as a god, "now or one day", if Rome is ever to "stand upright with neck unfettered" (603-4, where cervice soluta approvingly responds to Cato's words at 380, "indomita ceruice", and 261, "ceruice uacanti").

The scene in which Cato refuses the water a soldier has brought him is one of the opportunities for Lucan to compare his hero with Alexander, who is reputed to have done the same. Ahl understands it very well: "He

\footnotetext{
${ }^{40}$ Observe 268, ite, and 272, uadite securi; an identical attitude is altogether clear in Plutarch's biography of Cato (see 56.1, 64.7, and 65.1-2).

${ }^{41}$ Trans. Braund.
} 
[...] wishes to convey the notion that it is wrong for any man to be satisfied while others are suffering - the same principle that led Cato to involve himself in the civil war in the first place ${ }^{\prime \prime 2}$ At the same time, it is a practical demonstration of the principled rejection of privilege Cato defended at $398^{-}$ 402. Just as Alexander is the ultimate individualistic tyrant, Cato drives Roman republicanism beyond even its historical limits. This, we could relate to the echoes of the Iliad (2.84-368) in the mutiny scenes. It is interesting to note that, while Odysseus beats Thersites and tries to reassert the structure upon which the Greek leaders' power stood, Cato talks of equality of rank, the exploitation of the soldiers by their leaders and of liberty ("nunc iugulos ensesque negatis, / cum prope libertas?"). ${ }^{43}$ We must admit, however, that libertas here may not possess the content we would expect it to carry. Put in the context of Cato's political pessimism, this idea of the proximity of libertas cannot mean anything but inner freedom, or perhaps freedom acquired through death. ${ }^{44}$ Yet there is at least one political lesson to be learned, and the dialogue deals again with the problem of the danger of autocracy that Pompey's power represented. The soldiers are quite straightforward in the justification of their flight. That it seems natural for them to confess that their only loyalty was to Pompey shows how deeply their mentalities were estranged from Cato's way of reasoning. ${ }^{45}$ And it shows that Cato's position as unus homo ${ }^{46}$ has its particularities. More than in the case of Pompey or of Caesar, there is an element of loneliness in his plight. Nevertheless, Cato must play the role of a teacher of his men. He must strive to inculcate a completely different ideology. The pervasiveness of Stoic language in Cato's speeches, as demonstrated by Helzle ${ }^{47}$ differentiates Cato's discourse from that of the other main characters. The very terminology he employs is therefore likely to present difficulties to his interlocutors.

The hero's didactic work in this particular scene is presented through the simile of the bees drawn back to their work and love of honey (285-92), as if Cato's role were to bring the warriors back to their nature. The method used by Lucan's beekeeper to call back the insects, that is, by beating cymbals, is found in Vergil G. 4.64 as part of a strategy to attract

${ }^{42}$ Ahl 1976, 259.

${ }^{43}$ Cf. von Albrecht 1970, 275 with n. 2, Lausberg 1983, 221-3, and 1985, 1602.

${ }^{44}$ For death as liberation from slavery or suffering, a frequent idea in Seneca, see e.g. Sen. epist. 70, esp. 12, 14, 16-17, 19, 21, 24, and epist. 77.14-15. Cf. Rolim de Moura 2008, 127 with n.3, and Summers 1910, 252-4.

${ }_{45}$ On the soldiers' motives, see the poet at 5.244-8 (cf. 4.382-401).

${ }^{46}$ For which see Hardie 1993, 11.

${ }^{47}$ Helzle 1996, 138-43. 
the bees to the hive. ${ }^{48}$ Both poets describe the instrument as pertaining to the cult of Cybele. This similarity is noteworthy in the light of what differentiates Lucan from his probable model. Apiculture in Georgics 4 is approached through politically-charged language, especially in lines 67-102, which depict a battle of the bees and prescribe the killing of the vanquished queen (though Vergilian zoology conceives of it as a rex); and at $149-218$, which explicitly compare the community of the bees to human society. ${ }^{49}$ The reader ends up with a favourable image of the unconditional obedience to the monarch observed by the insects. In Vergil, the analogy with politics breaks down precisely due to the need of a beekeeper, which is the role Cato plays in Lucan's politics. In other words, Cato's speech has tried to counteract not only pure indiscipline but also the ideology of loyalty to the warlord after whose death the soldiers are willing to disperse, like bees when their queen is lost, as in Georgics 4.212-14. The simile employed by the narrator approvingly responds to the character's discourse: Cato comes as a husbandman who will direct the activities which the "king" has failed to organise productively.

\section{NATURE, AFRICA'S GEOGRAPHY, AND THEIR FUNCTION IN THE DIALOGUE}

The interest in nature, so typical of Lucan, both from a sensory and from a scientific/philosophical perspective, will appear once again in his digression on the Syrtes. A key sententia for this book, in a not very orthodox way of looking at nature if we think of an optimistic Stoic background, appears at 302: "hanc [sc. naturam] audax sperat sibi cedere uirtus". Perhaps a certain influence of Cynicism is visible here. ${ }^{50}$ The way Lucan explains the Syrtes seems to have an important allegorical meaning: ${ }^{51}$ the

${ }^{48}$ Cf. Var. R. 3.16.7, 3.16.30, and Arist. HA 627a.15-17.

${ }_{49}$ This link between animal and human societies in Vergil's poetry is emphasised by the repetition of G. 4.162-4 and 167-9 at A. 1.431-6, where the bee imagery is used to describe the Carthaginians at work. Cf. Var. R. 3.16.4-9, 3.16.18, 3.16.30, Arist. HA 488a7-13, 553a.17-554b.21, and 623b.17-627b.22.

${ }^{50}$ See again Sen. Dial. 1.3.14 (quoted above) for the philosopher's view of Cato's relationship with nature (taken almost as a synonym of "fate" in the passage), somewhat contrasting with Lucan's way of putting it. For the wise defying Fortune in Cynicism and Seneca, see Oltramare $1926,57,282$.

${ }^{51}$ For allegorical interpretation of book 9, a common approach to this part of the poem, see e.g. Fantham 1992, Leigh 2000, Malamud 2003 and Bexley 2010. Allegoresis is a consistent tradition in Stoicism, for which see Most 1989; cf. D'Alessandro Behr 2007, 107-11. I think we are allowed to suppose that Lucan made free usage of the poetic-symbolic possibilities therein. 
idea of an ambiguous condition (more clearly at 304, "[sc. natura] in dubio [...] reliquit"; 307, "ambigua [...] lege"; and 336, "dubioque [...] fato") constitutes the central motif of Lucan's description of the shallows, and this ambiguity is said not to have been intentional but to have come as a result either of carelessness in nature's plan (310-11: "sic male deseruit nullosque exegit in usus / hanc partem natura sui"), ${ }^{52}$ or of a dispute between the sea and the water-drinking Sun ("sua lumina pascens"), who is closer to the earth in Libya. ${ }^{53}$ This fight, however, has no clear purpose in terms of "intelligent design", that is, in a Stoic Weltanschauung which assigns the organisation of nature to a rational god. It may be an acceptable explanation in terms of the physics of Lucan's time and it is presented as an alternative to the other theory only in as far as it offers a scientific law to be substituted for the lack of order in the previous interpretation. These elements of irrationality will be mirrored in the way the narrator and the soldiers perceive nature during the march.

The trajectory itself is rather confusing. ${ }^{54}$ At $297-8$ we are at Cyrene (later, at 874 , "Cyrenis etiamnunc bruma rigebat", the place is felt by the troops to have been recently visited). They then try to reach Juba's kingdom (300-1, "Libyci contermina Mauris / regna Iubae") but are blocked by the Syrtes. Lake Tritonis, close to the "Hesperidum hortus" (358), is the next place to be cited. When in 368 the text reads "his igitur depulsa locis eiectaque classis", I feel, along with Housman ad loc., that the demonstrative refers to the gardens of the Hesperides and Lake Tritonis. But at 347 the fleet had reached the lake because of the hindrance of the Syrtes, so that it is strange to say at 368-9 that it is driven away from or by the lake and the garden by the Syrtes. This prompts Housman to suggest the correction "hos [...] locos", apparently solving the problem with an accusative of place to..$^{55}$ The passage becomes even more problematic with the use of "Tritonos [...] paludem" at 347, a name that may be applied to the Tritonis palus (or Salinarum lacus) of Africa Proconsularis, to the west of the Minor

\footnotetext{
${ }^{52}$ Cf. 435-7 (on the coast along the Syrtes): "et nulla sub illa / cura Iouis terra est; natura deside torpet / orbis."

${ }^{53}$ Cf. Hdt. 2.24

${ }^{54}$ For a comparison between the journey as it is described in history and Lucan's version, see Wuensch 1930, 35-7, 41-2, and Wick 2004 v.1, 5-8. The principal ancient sources for the journey are Liv. perioch. 112, Str. 17.3.20, Sen. Ep. 104.33, Plu. Cat. Mi. 56.6-8, Vell. 2.54.3, D.C. 42.13.3-4. See also Thomas 1982, 121 n. 27.

${ }_{55}$ Ahl $(1976,259)$ does not seem to have any problem with the interpretation of this passage: "The treacherous nature of the sandbanks combined with the fury of a tempest wreck several republican ships and drive the remainder far off course". They are "stranded in a remote part of Africa, at the site of the Garden of the Hesperides and close to the river Lethon". Ahl (1976, 261) reads lines $368-71$ as indicating that the men would rather stay there: "This simple observation gains from the site's proximity to the river Lethon". See Wick 2004, ad 355.
} 
Syrtis; but, with the indications that it should be near the Lethon and the garden of the Hesperides, it can be understood to be another palus, about 5 miles to the north-east of Berenice, i.e. on the opposite side with regard to the Syrtes..$^{56}$ As at 369 we actually have another landmark ("Syrtibus haut ultra Garamantidas attigit undas", the Garamantes dwelling in a vast area to the south of the Syrtes, in fact quite far from the sea), we probably must conclude that Lucan referred to the more easterly place..$^{57}$ Then Cato, with some men, will try to march round the Syrtis (373) while the fleet stays in a better place, supposedly near these "Garamantian waves". At 511, in a detour famously absent from the historical tradition, the group arrives at the oasis of Ammon, which is far to the east of Garama and the Syrtes. During the attack of the snakes, though, they seem to be again on the beach, near the Syrtes (756: "[Aulus] nunc redit ad Syrtes et fluctus accipit ore"). Although the Psylli are usually located in Syrtica, at 893 the Romans are said to meet the Psylli "of Marmarica", which would seem to imply that they are still near the sanctuary, to the east of Cyrene, or could even mean another return to the east after Aulus' drinks at the Syrtes. ${ }^{58}$ Finally, at $948-9$ they reach Leptis (Magna or Minor?) ${ }^{59}$ to pass the winter. It is difficult to believe that Lucan was thoroughly ignorant of African geography. His familiarity with the ancient ethnographical tradition suggests that he had read about Libya. ${ }^{60}$ In all probability, the poet was aware of his bizarre treatment of relative distances or, if these oddities are to be interpreted differently, he deliberately relocates certain peoples and sites from the places where they are to be found according to other sources. On the other hand, Bourgery shows that Lucan's poem contains many geographical inaccuracies, ${ }^{61}$ and I think that not all can be easily explained as intentional distortions. One should never exclude the possibility of the poet being careless or mistaken.

${ }^{56}$ Aumont $(1968,307-15)$ is convinced that it is the western Tritonis palus that Lucan is talking about and that it is Gnaeus Pompey who gets there, not Cato. He claims that Lucan does not mean that the Lethon and the garden of the Hesperides are near Berenice. Compare Wick 2004, $128-9$, ad 348-367, § 1.

${ }^{57}$ Aumont $(1968,312)$ is aware that the Garamantians occupy a territory far from the sea but understands that Garamantidas undas designates "la portion de littoral délimitée par les longitudes extrêmes de ce territoire". Cf. Wick 2004, ad 511 sq.

58 See Wick 2004, ad 893: Marmaridae Psylli constitutes a "sachliches Problem", for the Psylli live in the region near the Syrtis Maior, whereas Marmarica is located in the area between Egypt and Cyrene. Marmaridae may have been employed loosely to designate Libya as a whole.

${ }_{59}$ That Cato reached Leptis is also implied by Sidon. epist. 8.12.13 (cited by Wick 2004, v.1, 6). Bourgery and Ponchont (1929, 153 n.3, 174 n.2) and Haskins (1887, ad 9.524 and 948) following the Comm. Bern. ad 9.948, think it is Leptis Minor. Aumont (1968, 314 n.3, 318-19) and Wick (2004, ad 523-4 and 948) believe it is Leptis Magna (in my opinion, the correct interpretation).

${ }_{60}$ See Pichon 1912, 34-42, Thomas 1982, 108-23.

${ }^{61}$ Bourgery 1928. See now the discussion in Schrijvers 2010. 
Some of the inaccuracies we find in Lucan, however, are not necessarily errors. As Aumont notes, ${ }^{62}$ there were several places called Ammon in Roman Africa: one must consider e.g. ps.-Scylax 109, which mentions such a place near the Syrtis Maior. ${ }^{63}$ Isn't that the suggestion of 4.673 ("confinis Syrtibus Hammon")? Also 9.523-5 point in that direction, apparently locating the oasis somewhere on the way from Berenice to Leptis. Or is this to be taken as an indication of the longitude alone, for the astronomical information provided at 9.528-32 implies a position much more to the south ${ }^{64} \mathrm{Obvi-}$ ously, the oasis of Siwah was by far the best known place with that name and, consequently, there was a high probability of baffling the reader by locating an Ammonium elsewhere, even if correctly. Assuming, for the sake of hypothesis, that Lucan knows about the places he alludes to and accepts their more traditional distribution over the landscape of North Africa, the poem presents us with an admittedly unbelievable trajectory.

Ironically, when Cato's men are beginning their journey at 375-7, the time of year (winter) gives them the hope of marching across the desert without too much trouble; the return of winter at the finishing point of the journey quite naturally adds an image of the circularity of time to the somewhat circular trajectory the expedition draws upon Libya's map. The description of the land, its climate, plants and soil (411-44) focuses on a motif of inactivity (and even decay; cf. 492, "qui nullas uidere domos uidere ruinas") that can have symbolic importance as well. Particularly odd is the means of subsistence attributed to the Nasamonians at 439-44: to collect the goods left behind after the shipwrecks caused by the Syrtes. Images of inversion of the usual natural conditions and problems of perception enhance the strangeness of the atmosphere: the soldiers experience sea-terrors on land; the earth is lifted up to the air (see esp. 458 , "regna [...] errantia uento"); the soil itself is unstable at $464-5$ (but it is the very instability of the sand that allows the deepest layers of the soil, the "ima tellus" at 470, to keep their place and not be carried away by the force of the wind) ${ }^{65}$ Lucan craftily distorts and omits information in order to emphasise his portrait of Libya as an extraordinary country, where man is not allowed to have perfect use of his senses. See e.g. 493-7:

${ }^{62}$ Aumont 1968, 316-17.

${ }^{63}$ See also Bourgery 1928, 36.

${ }^{64}$ By the way, a far too southerly position: as regards Siwah, the latitude implied would be wrong. See Pichon 1912, 37, and Housman 1926, 329-33.

${ }^{65}$ In this paradox, Lucan is playing with the traditional images of land as stable and sea as unstable. See Leigh 2004, 123 n.118 (cf. 145, 148-9, 152-4). 
iamque iter omne latet nec sunt discrimina terrae:

[ulla nisi aetheriae medio uelut aequore flammae] ${ }^{66}$

sideribus nouere uiam; nec sidera tota

ostendit Libycae finitor circulus orae,

multaque deuexo terrarum margine celat. ${ }^{67}$

And now their path was utterly hidden and all the landmarks were lost; they found their way by the stars; and the horizon which bounds the African continent does not display the constellations entire, but many are concealed by the curvature of the earth's rim. ${ }^{68}$

In the interesting apostrophe the poet directs at people living to the south of Libya (538-42), the expansion of his notional readership to include extremely remote people, whose existence he seems not even to be sure of, is a candidate for the greatest rhetorical extravaganza in the poem and adds to the oddness of the section. The journey is filled with ambages and so is Lucan's style in book 9. His representation of Libya's nature and geography gives the impression that the narrator is no less confused and astonished by the region than the soldiers are. ${ }^{69}$ His views on Africa's fauna, atmospheric conditions, geographical accidents and routes all converge to produce that impression. This can be seen as the mere result of ignorance on the part of the author but it more probably expresses the narrator's emotional-valuational stance, in direct response to his characters' suffering. The poet immerses himself in the dangers of Libya as an anxious participant in Cato's expedition.

\section{CATO UNDER ATTACK AGAIN: LABIENUS, THE SOLDIERS' LAMENT, AND THE POET'S COMMENTS}

At the temple of Ammon, Labienus' speech, as we have seen, is undoubtedly designed to question Cato's ethical stance. Lines 561-3 are in my view the most important: "tua pectora sacra / uoce reple; durae saltem uirtutis amator / quaere quid est uirtus et posce exemplar honesti" ("fill your breast with the sacred voice; as a lover of severe virtue, ask at least what virtue is and demand a model of righteousness"). This is clearly provocative, all the

${ }^{66}$ Om. MPUV : del. Bentley.

${ }^{67}$ Housman ad loc.: "plura Libya quam Italia sidera uidet, sed illa quibus ducibus nautae utebantur non semper tota."

68 Trans. Duff.

${ }_{69}$ See Lowe 2010, 128: "Both Lucan's treatment of myth and his narrative style reflect the instability of the Libyan environment itself". 
more because of the studied ambiguity based on the anceps position of the last syllable of 561 . If he needs to fill his breast with a sacred voice, this naturally hints at the possibility that he could not have this voice inside him. The alternative translation, "fill your sacred breast with a voice", would be almost outrageous, if not to impassive Cato, at least to many scholars; but there is nothing I can do against the rules of the hexameter... One must consider, of course, that the "rule" of even distribution of noun and epithet is perhaps at play here as well, so that it would be more "natural" to take sacra with uoce, but this does not preclude the ambiguity from arising. ${ }^{70}$ If Cato were to ask the oracle what virtue is and ask for a "model of rectitude", this would be to admit he has failed in his educative project, that he could not occupy the model role he pursues to be. According to Labienus, he is a lover of a dura uirtus, and would need to ask what uirtus (tout court) is. This way of presenting the idea is bound to insinuate that the virtue he loves is only a derivative kind of virtue, the severe one. When the narrator introduces Cato's answer, it is remarkable that he echoes Labienus' words (564: "ille deo plenus"; 565: "effudit [...] e pectore uoces") and contradicts his ironic innuendoes. Cato, for his part, speaks to champion his authority as a master of wisdom because he centres the arguments on the idea that he and, consequently, his students already know what must be known. Pichon argues that Cato's decision is coherent with Stoic views on divination, which regarded it as possible but morally irrelevant. ${ }^{71}$ Nonetheless, at 5.102-14 Lucan praises the beneficial qualities of the oracle at Delphi, the advice from which has enabled man to found prosperous cities, avert wars and put an end to pestilence. Lucan is talking about practical measures which can be taken within the constraints determined by the Fates. Implying no change in the main sequence of predestined events, these measures possess exclusively local importance. When Cato rejects Labienus' suggestion to consult Ammon, he quite coherently explains that the oracle cannot teach them the basic philosophical principles they should already be aware of. However, in the face of the practical difficulties encountered by the soldiers in the harsh Libyan environment, not to mention their finding it hard to grasp Cato's ethics, one wonders whether the oracle could not offer up a suggestion or even confirm the general's philosophy, thus bestowing more authority upon it. Again, we observe that an abyss separates the worldview proposed by Cato from an attitude which his men might arguably think more useful.

${ }^{70}$ Cf. Ahl 1976, 264.

${ }^{71}$ Pichon 1912, 186-200. See Sen. Nat. 1.1.2-4; 2.32, 35-6; 59.1-4. 
However, when the hardest tests come, no political or moral principle can make any sense to dipsas-struck Aulus (9.747-9): "non decus imperii, non maesti iura Catonis / ardentem tenuere uirum, ne spargere signa / auderet". After the poor soldier's death, it is remarkable that Cato seems to be in denial. Let us observe the narrator's words at 761-3: "iussit signa rapi propere Cato: discere nulli / permissum est hoc posse sitim. sed tristior illo / mors erat ante oculos". Cato bid the standards be hurriedly snatched away: to nobody it was allowed to learn that thirst had power to do this. But a more dreadful death than that was in full view: it is the seps' turn to attack. (The signs of an avoidance of reflection in Cato's attitude are heightened by the parallel with 1.205, [Caesar] "signa tulit propere": it is the fording of the Rubicon, a scene where Caesar's irrationality is to the forefront). At this point of book 9, we are entering a passage where the importance of visualisation is perhaps surpassed by no other in Lucan's oeuvre. At 741, 789, and 822 , we are introduced to the grim ecphraseis by an enthusiastic ecce. At 805, the wondrous display of gore is dubbed spectacula while, in 832 , we reach the culmination of "exemplarque sui spectans miserabile leti" ("gazing at the pitiable image of his own death")..$^{72}$ The reaction of Cato at 761-2 provides us with the first clear instance in which he prefers to hide the truth from his pupils. The narrator is keen to comment upon the inefficiency of Cato's sudden act of evasion: note the force of sed and ante oculos in 762-3.

It is all too much. When the lament of the soldiers is about to begin, their descent into confusion is almost complete: $846-7$, "nec, quae mensura uiarum / quisue modus, norunt caelo duce"; their brains are wrecked; they do not know for sure where exactly they are (871-8), not even knowing if they are still in Africa (873-4). The impression of disorder in nature's laws is pervasive: $866-7$, "coeunt ignes stridentibus undis / et premitur natura poli"; or 875, "legem conuertimus anni"? The discourse is impregnated with a deep sense of the absurdity of their trip and expresses great confusion about the purpose of this effort: at 867-9, "fama cognita nobis / tristia regna Iubae", Juba's land is imagined as a distant place known only "by rumour" (Braund). At 850, on the other hand, the use of "inactive deaths" (segnia fata, sc. instead of proper fight) clearly shows that the lesson was only partially assimilated, and may be a hint at the shortcomings of Cato's participation in the war (it is a known fact that he hardly engaged in battle during the conflict). The speech seems to be preparing for the moment

${ }^{72}$ Cf. 815-21: Laeuus' death, by the bite of the Niliaca serpens, is immediate and without pain and does not have the characteristics of a spectacle (see 815: at), although the extraordinary speed of this poison's effect is observed by the narrator. Also the death caused by the iaculus is quick, but visually striking as well (822-7). For the snakes episode as a spectacle, see Leigh 1997, $273-82$. 
when Cato will finally be completely abandoned in Utica. If Lucan intended to follow history here, we must see that, while showing the slow process of destruction of Cato's relationship with his soldiers, ${ }^{73}$ the poet is not necessarily rebelling against his venerable character; he may be merely developing what the biographical and historical sources preserved.

The soldiers' speech conveys an impression of contradictory passions and incoherent wishes, even complete madness. Note, for instance, 848-9: "reddite, di [...] / reddite Thessaliam", but then the desire to die by the effect of excessive heat (852-4); still, as perhaps there are worse things to come (865-6), the serpents may be a better fate ("quaeremus forsitan istas / serpentum terras: habet hoc solacia caelum: / uiuit adhuc aliquid", 869-71). And the last desire (878-80): "solacia fati / haec petimus: ueniant hostes, Caesarque sequatur / qua fugimus". This does not sound like a lesson of basic military strategy but there is surely a suggestion that something else should have been done: probably fight, instead of indulging in segnia fata. $^{74}$ The close of the speech, revealing the wish that Caesarean forces follow them in their escape, is a grim response to Cato's criticism of fuga at 283 ("ignauum scelus est tantum fuga") and to his idea that the evils of Libya alone can make their escape one that is suitable for men (405-6: "sola potest Libye turba praestare malorum / ut deceat fugisse uiros"), these two occurrences of fug- in Cato's discourse being located also at the close of two important speeches. The dialogical link is evident.

The narrator interrupts the soldiers' speech with this ambiguous comment: "sic dura suos patientia questus / exonerat. cogit tantos tolerare labores / summa ducis uirtus". It seems to me that dura patientia is somewhat inadequate to describe the soldiers' mental confusion, and the very fact that tough endurance "disburdens itself of its complaints" ${ }^{\prime \prime 75}$ is at odds with the narrator's remark at 886-7, "puduit gementem / illo teste mori" (Braund: "in his presence they were ashamed to die with groans"). If the narrator admits that the complaints are an instrument of dura patientia for relieving the men of their suffering (Rowe's translation at 9.1501 grasps the spirit of the passage), why be ashamed of groaning? After all, it was the voice of Cato that impressed patientia upon the troops (292-3, the narrator's comments on a previous speech) and our general himself is the author of the striking sententia at 403, "gaudet patientia duris". But the verb cogit at 881 (constrained,

\footnotetext{
${ }^{73}$ Observe that the soldiers have no complaint against nature or Africa (854-8): it is obvious that nature's intention was to leave the region uninhabited by humans. This is connected with the concept of divine punishment for the hybris of entering this land (859-62).

${ }^{74}$ For the desire of a "good" death in battle, not a useless one (by drowning), cf. e.g. Verg. A. 1.94-101.

75 Trans. Haskins 1887, ad loc.
} 
forced) reveals that the soldiers' endurance is perhaps more than they can take. Likewise, at 292-3, "sic uoce Catonis / inculcata uiris iusti patientia Martis", the participle inculcata denotes "forced upon". ${ }^{76}$ Significantly, the soldiers' speech is given no reply by Cato, just as Marcia's speech in book 2 is met with Cato's silent response alone. The breakdown of communication between Cato and the soldiers indicates that Cato's "meaning" has not succeeded in getting through to the addressee and, however hard Lucan tries to endorse the views of his hero, one cannot help but feel that even the poet's stance is one of anxiety and uncertainty. Actually, Cato's last speech in book 9 (and in the poem) is at 612-16, after which we are confronted with the Medusa excursus, the catalogue of snakes, their attack, and finally the Psylli episode. The narrative orders the material so that a trajectory from rational discourse to the collapse of rationality is implied. The final move is into the realm of incantation represented by the Psylli.

\section{CONCLUSION}

In book 2, the dilemma facing Cato and Brutus was circumscribed by the possibility of Pompey's victory and the political scenario that it would entail. Now, at the other extreme of Lucan's poem, Pompey has not only been defeated and killed but has also given all possible proofs of his inadequacy as a republican. In Lucan 9, there seems to be little point in (or indeed little chance of) confronting Caesar's army in the near future. Lucan envisages the republican forces under Cato's command as a group of men stranded in Africa and in need of reorientation. Cato can now be sure that the fight must be transferred to another sphere, that of ideas.

The relationship between this march through the desert and the journeys to other worlds typical of the Menippean satire, established by Şerban, is accurate. ${ }^{77}$ Certainly we are witnessing a test of Cato's philosophy in extremely adverse conditions, as if it were a chemical experiment performed outside the lab, in uncontrolled circumstances. ${ }^{78}$ To claim that it is only designed as praise of his wisdom and courage is certainly far too

${ }^{76}$ Cf. Sen. Dial. 10.7.3. For the fact that the soldiers' speech points to a contrast between their "Folie" and Cato's "Übermenschentum", see Schmitt 1995, 191. Cf. Cazzaniga 1957, 28-9, who also observes the strong similarities between the troops' lament and Albinovanus Pedo's fragment at Sen. Suas. 1.15.

${ }_{77}$ Şerban 1973, 47-51.

${ }^{78}$ For this characteristic of the Menippean satire, see Bakhtin 1984, 114-16. 
narrow an interpretation though. ${ }^{79}$ Recent scholarship has divined many other aspects of this difficult text. However, to commit the opposite error, i.e. to reduce the book to a mere attack on radical Stoicism, is not helpful either: the book does indeed criticise Cato's strict philosophy, and his qualities as teacher and military leader as well, but the general's inner strength and emotional balance, as opposed to the dissolution of the narrator's conscience and the soldiers' intellectual and psychological helplessness, must likewise be observed. Of course, one could even argue that, if the disastrous journey offers the occasion for such an epistemological loss in the narrator and in the poor troops, Cato is maybe responsible, for, being a madman, he contaminates everything with his madness. Cato's madness would then be the type found in Don Quixote. He can converse knowledgeably, employs discreet language, champions most noble principles of chivalry and is aware of almost everything, except his own madness (something we could not say about Cato's soldiers, for example, who are perfectly aware of their own minds' insufficiency). ${ }^{80}$ The elements of denial in Cato's behaviour (as in the dipsas episode and, to a certain extent, in his refusal to consult Ammon) point to a man who attempts to suppress his self-doubt or avoids measuring his views against other authorities (such as those represented by nature and the gods). Does Cato's case, understood within these lines of interpretation, deserve the label of idiocy? Surely it does, at least from the viewpoint of other forms of consciousness within the poem. But what shall we think when the diagnosis is made by mad doctors?

Since the narrator does not attain perfect "outsideness" in relation to his characters, ${ }^{81}$ the moral and intellectual dilemmas faced by Cato and his men are presented as something which is still open to judgement. The poet cannot interpret their significance with the detachment provided by historical (and temporal) distance. In other words, although temporally separated from the characters, the narrator still sees the world from their perspective, so that, morally speaking, their future is also his future. Their fight is continued by the ideological struggle the narrator is immersed in. When

${ }^{79}$ Seo (2011) shows how Cato's status as an exemplum uirtutis in Roman imagination may have shaped the ancient reception of Lucan's narrative, which appears to modern readers as exaggerated and perhaps funny. However, as the article also suggests, one has to consider that the Romans themselves sometimes pointed out that Cato was too severe, somewhat unrealistic in his approach to politics and maybe even inadequate as an exemplum. Note e.g. Cic. Mur. 60 and Sen. Ep. 11.10.

${ }^{80}$ A parallel in modern literature would be Lear in the second half of Shakespeare's tragedy.

${ }^{81}$ See V. Liapunov (apud Bakhtin 1990, 235 n.28): "Bakhtin contracts the Russian phrase nakhodit'sja vne (to be situated or located outside the bounds of someone or something) into a noun - vnenakhodimost' (the state of being situated outside the bounds of). It should be stressed that this situatedness outside (the bounds of) the hero is a position assumed in relation to the hero or toward the hero. Other translators have preferred to render vnenakhodimost' as 'extopy' or 'extra-location'." 
faced with the task of representing the characters' failure to make sense of their journey, the narrator must acknowledge that he himself is unable to justify it clearly. This is shown by the unnecessary weight given to mythology and by the inconsistencies in his handling of African geography, strong arguments for the view of the narrator as a voice whose concrete manifestation is visible not only through apostrophes and explicit moral judgements but also in the organisation given to the materials of the story, in a word, through his syuzhet. ${ }^{82}$ This comprises e.g. the architectonics of space in Libya and the strategic insertion of mythological stuff, and, being part of the narrator's voice, constitutes a part of his reply to the issues brought up by the characters. The apparent detour to the oasis of Siwah, for example, could therefore be conceptualised as part of a dialogue. ${ }^{83}$ Given Cato's selfassuredness, the decision to confront him with Ammon (ultimately, with Zeus himself) suggests arguably the most climactic dialogue the Bellum Ciuile could aspire to stage, the one between the two moral standards opposed at 1.127 ("uictrix causa deis placuit, sed uicta Catoni"). This dialogue is only partially realised through Cato's refusal to make Ammon speak and his justification of that decision. This is an ambiguous response on the part of the narrator. It can either imply that he approves of Cato's radicalism (as the strength of Cato's faithfulness to his personal truth is indeed admirable) or that he wants to expose it as a dangerously self-centred dogmatism.

The aesthetic achievement of Lucan's portrait of Cato goes beyond both the burlesque cartoon and the stereotyped idealisation of a Stoic saint. The character resists categorisation and keeps secret an inner reality that defies both the critics and the poet himself. Apparently Lucan and his anxious and ignorant narrator fail to consummate ${ }^{84}$ the image of the hero as something definitely good or evil, or to ascribe a clear significance to a trajectory that breaks off so enigmatically: simultaneously the object of the highest hopes and the cause of most painful disappointment, Cato is maybe the subtlest figure in Lucan's epic. In other words, his ambiguity is not just the result of the probably unfinished state of the poem, but is the product of a complex artistic and ideological stance: the narrator undoubtedly identifies in Cato aspects of the fight for liberty that he cherishes so

${ }^{82}$ For the concept, see Lowe 2000, 5, 17-19. Note Tipping 2011, 236: “Lucan's repeated refusal to allow Cato to avoid the spectacle of pain pushes to a point of absurdity the tendency of plot to put character under pressure."

${ }^{83}$ See Bakhtin 1990, 4; every constituent of a work represents the author's reaction to that constituent: "this reaction encompasses both an object and the hero's reaction to that object (a reaction to a reaction); [...] the author intonates [...] every trait of his hero [...], just as in life, too, we react valuationally to every self-manifestation on the part of those around us."

${ }^{84}$ For the process of consummation of the hero's image by the author, see Bakhtin 1990, 4-231. 
much, but this does not lead him to forget the impending demise of Roman society, nor does it obscure the ideological contradictions in that society, a predicament he feels Cato is part of, and the narrator himself is not immune to. The character's inner loophole, needless to say, overlaps with the inner open-endedness of the narrator himself as he does not achieve a position of complete exteriority in relation to the fight he recounts. ${ }^{85}$

\section{BIBLIOGRAPHY ${ }^{86}$}

Lucan is quoted in accordance with:

Housman, A. E. ed. 1926. M. Annaei Lucani Belli Civilis libri decem. Oxford: Blackwell.

I have often consulted (and sometimes quoted from) the following English translations of Lucan: ${ }^{87}$

Braund, S. H. 1992. Lucan, Civil War, trans. with introd. and notes. Oxford: Oxford University Press.

Brown, S. A.; C. Martindale. eds. 1998. Lucan, The Civil War, trans. N. Rowe. LondonVermont: Everyman.

Duff, J. D. 1928. Lucan, The Civil War (Pharsalia), with an English transation. Cambridge, Mass.: Harvard University Press-London: Heinemann.

Ahl, F. 1976. Lucan: an introduction. Ithaca; London: Cornell University Press.

Aumont, J. 1968. "Caton en Libye (Lucain, Pharsale, IX, 294-949)." REA 70: 304-20.

Bakhtin, M. M. 1984. Problems of Dostoevsky's poetics. Ed. and trans. C. Emerson. Manchester: Manchester University Press.

Bakhtin, M. M. 1990. Art and answerability: early philosophical essays. Ed. M. Holquist; V. Liapunov, trans. V. Liapunov; K. Brostrom. Austin: University of Texas Press.

Bexley, E. 2010. "The myth of the republic: Medusa and Cato in Lucan, Pharsalia 9." In Lucan's "Bellum Ciuile" between epic tradition and aesthetic innovation, eds. N. Hömke; C. Reitz, 135-53. Berlin-New York: Walter de Gruyter.

Bostock, J.;H.T. Riley. 1890. The Natural History of Pliny, v. 2. London: George Bell \& Sons. Bourgery, A. 1928. "La géographie dans Lucain." RPh (3rd) 2: 25-40.

Bourgery, A.; M. Ponchont. 1929. Lucain, La Guerre civile (La Pharsale), v. 2. Paris: Les Belles Lettres.

${ }^{85}$ Thanks to Georgios Kazantzidis, Robert Williams, Henrique Cairus, Matthew Leigh, Rhiannon Ash, William Fitzgerald and to audiences at São Paulo and Brasília.

${ }^{86}$ For periodicals, I use the abbreviations of L'Année Philologique.

Email do autor: alessandro.rolimdemoura@gmail.com

${ }^{87}$ Some translations are my own (this being the case where no author is indicated). 
Cazzaniga, I. 1957. "L'episodio dei serpi libici in Lucano e la tradizione dei 'Theriaka' nicandrei." Acme 10: 27-41.

D'Alessandro Behr, F. 2007. Feeling history: Lucan, Stoicism, and the poetics of passion. Columbus: Ohio State University Press,.

Davie, J. 2007. Seneca, Dialogues and Essays. Oxford: Oxford University Press.

Eldred, K. O. 2000. "Poetry in motion: the snakes of Lucan." Helios 27: 63-74.

Fantham, E. 1992. "Lucan's Medusa excursus: its design and purpose." MD 29: 95-119.

Fränkel, H. 1968. Noten zu den Argonautika des Appolonios. Munich: C. H. Beck.

Hardie, P. 1993. The epic successors of Virgil: a study in the dynamics of a tradition. Cambridge: Cambridge University Press.

Haskins, C. E. 1887. M. Annaei Lucani Pharsalia. London: George Bell \& Sons. Cambridge: Deighton, Bell \& Co.

Helzle, M. 1996. Der Stil ist der Mensch: Redner und Reden im römischen Epos. Stuttgart-Leipzig: Teubner.

Hershkowitz, D. 1998. The madness of epic: reading insanity from Homer to Statius. Oxford: Clarendon Press.

Hutchinson, G. O. 1993. Latin literature from Seneca to Juvenal: a critical study. Oxford: Clarendon Press.

Johnson, W. R. 1987. Momentary monsters: Lucan and his heroes. Ithaca; London: Cornell University Press.

Kany-Turpin, J. 2005. "Méduse et l'épidémie. La métamorphose d'un mythe dans la Pharsale (IX, 619-889)." In Liber amicorum. Mélanges sur la littérature antique et moderne à la mémoire de Jean-Pierre Néraudau, eds. F. Lestringant et al., 133-45. Paris: Honoré Champion.

La Penna, A. 1980. "Mezenzio: una tragedia della tirannia e del titanismo antico." Maia 32:3-30.

Lausberg, M. 1983. "Iliadisches im ersten Buch der Aeneis." Gymnasium 90: 203-39.

Lausberg, M. 1985. "Lucan und Homer." ANRW II 32.3: 1565-622.

Leigh, M. 1997. Lucan: spectacle and engagement. Oxford: Clarendon Press.

Leigh, M. 2000. "Lucan and the Libyan tale." JRS 90: 95-109.

Leigh, M. 2004. Comedy and the rise of Rome. Oxford: Oxford University Press.

Lowe, D. 2010. "Medusa, Antaeus, and Caesar Libycus." In Lucan's "Bellum Ciuile" between epic tradition and aesthetic innovation, eds. N. Hömke; C. Reitz, 119-34. Berlin-New York: Walter de Gruyter.

Lowe, N. J. 2000. The classical plot and the invention of Western narrative. Cambridge: Cambridge University Press.

Malamud, M. 2003. "Pompey's head and Cato's snakes." CPh 98: 31-44.

Masters, J. 1992. Poetry and civil war in Lucan's Bellum Ciuile. Cambridge: Cambridge University Press.

Morford, M. P. O. 1967. "The purpose of Lucan's ninth book." Latomus 26: 123-9.

Most, G. 1989. "Cornutus and Stoic allegoresis: a preliminary report." ANRW II 36.3: 2014-65.

Narducci, E. 2001. "Catone in Lucano (e alcune interpretazioni recenti)." Athenaeum 89: 171-86.

Oltramare, A. 1926. Les origines de la diatribe romaine. Geneva: Imprimeries Populaires. 
Pichon, R. 1912. Les sources de Lucain. Paris: E. Leroux.

Rolim de Moura, A. 2008. Speech, voice, and dialogue in Lucan's Civil War. Oxford: D. Phil. Diss. - University of Oxford.

Rose, P. W. 2006. "Divorcing ideology from Marxism and Marxism from ideology: some problems." Arethusa 39: 101-36.

Saylor, C. 2002. "Vana species leti: Cato's march in Lucan, Pharsalia IX." In Hommages à Carl Deroux, ed. P. Defosse, v. 1, 458-63. Brussels: Latomus.

Schmitt, A. W. 1995. Die direkten Reden der Massen in Lucans Pharsalia. Frankfurt: P. Lang.

Schrijvers, H. 2010. "L'espace géographique dans le récit lucanien. Lucain et Ératosthène de Cyrène." In Lucain en débat. Rhétorique, poétique et histoire, eds. O. Devillers; S. F. d'Espèrey, 267-79. Bordeaux: Ausonius.

Shoaf, R. A. 1978. "Certius exemplar sapientis uiri: rhetorical subversion and subversive rhetoric in Pharsalia 9." PhQ 57: 143-54.

Sell, R. 1987. "The comedy of hyperbolic horror: Seneca, Lucan and $20^{\text {th }}$ century grotesque." Neohelicon 11: 277-300.

Seo, J. M. 2011. "Lucan's Cato and the poetics of exemplarity." In Brill's companion to Lucan, ed. P. Asso, 199-222. Leiden-Boston: Brill.

Şerban, G. 1973. Les fonctions du fantastique dans la Pharsale. Bucharest: Ovidianum.

Summers, W. C. 1910. Select Letters of Seneca. London: Macmillan.

Thomas, R. F. 1982. Lands and peoples in Roman poetry: the ethnographical tradition. Cambridge: The Cambridge Philological Society.

Tipping, B. 2011. “Terrible manliness? Lucan's Cato." In Brill's companion to Lucan, ed. P. Asso, 223-36. Leiden-Boston: Brill.

Viarre, S. 1982. "Caton en Libye: l'histoire et la métaphore (Lucain, Pharsale, IX, 294949)." In Neronia 1977: actes du $2^{e}$ colloque de la Société Internationale d'Études Néroniennes, eds. J.-M. Croisille; P.-M. Fauchère, 103-10. Clermont-Ferrand: Adosa.

Von Albrecht, M. 1970. “Der Dichter Lucan und die epische Tradition." Entretiens de la Fondation Hardt 15: 267-308.

Wick, C. 2004. M. Annaeus Lucanus, Bellum Ciuile, liber IX. Munich-Leipzig: K. G. Saur. 2 v.

Wuensch, M. 1930. Lucan-interpretationen. Leipzig-Berlin: Teubner.

\section{$*$}

Abstract. After Pompey's defeat at Pharsalus and his assassination in Egypt, Cato tries to reorganise the republican forces in North Africa. His fight is a political and philosophical one. Lucan presents this challenge by means of a fantastic crossing of the Libyan desert as well as through speeches by Cato and his interlocutors. This paper attempts to show how the shape of the narrative exposes the dilemmas faced by the characters and the narrator himself in this context of crisis. I shall address the order of the contents in book 9, the narrator's interventions, the use of direct speech and the manipulation of African geography.

Keywords. Lucan, Cato, narratology, Africa, geography. 